\title{
KAJIAN KOMPOSISI SERANGGA POLINATOR PADA TUMBUHAN PENUTUP TANAH DI PONCOKUSUMO - MALANG
}

\author{
Budi Purwantiningsih', Amin Setyo Leksono², Bagyo Yanuwiadi ${ }^{3}$ \\ 1 Program Studi PSLP, Program Pascasarjana Universitas Brawijaya, Malang \\ 2,3Pascasarjana Universitas Brawijaya, Malang \\ E-mail: vica_aji@yahoo.com
}

\begin{abstract}
The use of pesticides on agricultural land has a negative impact on health, economic, and environment. The using of variety of ground cover plants as refugia area are expected to be an alternative habitat for pollinators insect in plants: Cyperus rotundus L., Bidens pilosa L., Commelina difussa L., Capsicum frutescens L., and Ageratum conyzoides L .. Observations made by "visual control". This reseacch aims to know the composition of pollinators insect visit of ground cover plants and analyze their patterns. Analysis of the data structure of insect communities in the spring and the fruit season obtained from INP and diversity (Shannon-Winner Index). Parameters are compared to diversity and abundance with ANOVA test, composition using Morisita Index. The results show that the abundance of insect pollinators of spring higher at 7 families (31\%) with $H^{\prime}=1.698$ instead of the fruit season is 6 families $(25 \%)$ with $H^{\prime}=$ 1.600. Abundance and diversity of pollinators insect in the spring and fruit season with a significance of $P<0.05$. Morisita similarity index of $82 \%$. Analysis of environmental factors of temperature, humidity, and light intensity on the abundance of insect pollinators found positive correlation with $R$-square $87.5 \%$.
\end{abstract}

Keywords: Composition, pollinators insect, visual control, diversity

\section{PENGANTAR}

Penggunaan bahan-bahan kimia yang tidak tepat dalam mengendalikan hama dapat memberikan efek samping seperti hama sasaran menjadi resisten terhadap pestisida, resurjensi hama atau peningkatan populasi keturunanketurunan hama dibandingkan jika tidak diperlakukan dengan pestisida, matinya hewan non target termasuk musuh alaminya, timbulnya ledakan hama sekunder, pestisida tertentu dapat meninggalkan residu di dalam tanaman, pencemaran lingkungan baik tanah, air dan udara, dan berdampak pada kesehatan manusia (Bahagiawati, 2001).

Usaha pengendalian hayati bertujuan untuk memaksimalkan kinerja musuh alami yang ada di lahan pertanian adalah salah satunya dengan menciptakan habitat yang disukai oleh musuh alami, manajemen habitat ini dilakukan untuk meningkatkan jumlah populasi musuh alami. Manajemen habitat ini merupakan bentuk konservasi kontrol biologis, sebuah pendekatan yang berbasis ekologi yang ditujukan untuk mendukung musuh alami dan meningkatkan kontrol biologis dalam sisem pertanian, dengan tujuan untuk menyediakan sumber daya seperti makanan bagi musuh alami dewasa, mangsa atau inang alternatif, dan tempat berlindung dari kondisi yang merugikan (Landis, et al., 2000).
Raju \& Ezradanam (2002) dan Fahem et al., (2004) menyatakan bahwa pohon apel merupakan salah satu jenis pohon yang tidak dapat melakukan penyerbukan sendiri karena bunga apel tergantung pada serangga penyerbuk. Kualitas buah apel sangat ditentukan dari jumlah kunjungan serangga dan penyerbukan yang dilakukan oleh serangga polinator. Keberadaan serangga polinator sangat penting dalam mendukung keberhasilan proses penyerbukan sehingga pada akhirnya dapat meningkatkan kualitas dari tanaman apel.

Tumbuhan liar menjadi tempat berlindung dan berkembang biak bagi beberapa serangga khususnya serangga polinator. Serangga Polinator adalah serangga yang berperan dalam polinasi yaitu perantara penyerbukan tanaman. Penyerbukan tanaman merupakan proses pemindahan serbuk sari (polen) dari anther ke stigma (kepala putik) (Hadi et al., 2009).

Permasalahannya adalah banyak dari petani apel Poncokusumo yang menganggap bahwa tumbuhan penutup tanah yang tumbuh di sekitar perkebunan sebagai sumber hama dan penyakit tanaman sehingga petani membersihkan tumbuhan penutup tanah di pematang sawah pada awal musim bunga dan buah. Hal ini terjadi karena kurangnya pemahaman mereka terhadap peranan tumbuhan liar dan ketergantungan mereka akan pestisida. Faktor pengelolaan lahan merupakan faktor kunci dalam kelestarian serangga 
polinator, oleh karena itu, perlu dilakukan inventarisasi jenisjenis serangga tumbuhan penutup tanah, serta informasi mengenai jenis-jenis serangga polinator. Dengan demikian maka masyarakat dapat melakukan tindakan konservasi untuk melestarikan jenis-jenis tersebut.

\section{BAHAN DAN CARA KERJA}

Penelitian ini dilaksanakan di perkebunan Apel tepatnya di Desa Drigu Kecamatan Poncokusumo Kabupaten Malang Jawa Timur pada Bulan Mei 2011-Desember 2011.

Lokasi pengambilan sampel dipilih adalah kebun apel seluas kurang lebih $2000 \mathrm{~m}^{2}$ yang di bawahnya terdapat tumbuhan penutup tanah yaitu Bidens pilosa, Cyperus rotundus, Ageratum Conyzoides, Commelina difussa dan Capsicum frutescens (cabai).

Jenis penelitian yang digunakan dalam pengamatan serangga adalah penelitian deskriptif observasional, dengan menggunakan rancangan blok. Pengamatan serangga polinator tumbuhan penutup tanah diamati secara visual sebanyak lima kali pada hari berbeda yang dilakukan dengan empat periode, periode I pukul 07.00-18.15, periode II pukul 09.00-10.15, periode III pukul 12.00-13.15 dan periode IV pukul 15.00-16.15 masing-masing selama 15 menit setiap periode (Frei dan Manhart, 1992). Identifikasi serangga sampai tingkat famili dilakukan di laboratorium Ekologi dan Deversitas Hewan Jurusan Biologi, Fakultas Matematika dan Ilmu Pengetahuan Alam. Universitas Brawijaya.

Untuk analisis data Keanekaragaman pada setiap lokasi dihitung dengan Indeks Shannon-Winner. Sedangkan kesamaan spesies menggunakan Indeks Morisita. Diversitas dan kelimpahan dibandingkan dengan uji anova, sedangkan kesamaan komposisi mengunakan Indeks Morisita dengan rumus:

$$
\mathrm{CM}=\frac{\left(2 \sum \mathrm{Xi} . \mathrm{Yi}\right)}{((\mathrm{SA}+\mathrm{SB}) \mathrm{NA} \cdot \mathrm{NB})}
$$

Keterangan:

$\mathrm{CM}=$ Indeks Morisita

$\mathrm{NA}=\sum \mathrm{Xi}$ : Total jumlah individu di dalam komunitas A

$\mathrm{NB}=\sum$ Yi: Total jumlah individu di dalam komunitas B

$\mathrm{SA}=\frac{\left(\sum\left(\mathrm{Xi}(\mathrm{Xi}-1)\left(\sum(\mathrm{Xi}(\mathrm{Xi}-1))\right.\right.\right.}{\mathrm{NA}(\mathrm{NA}-1)}$

$\mathrm{SB}=\frac{\left(\sum\left(\mathrm{Yi}(\mathrm{Yi}-1)\left(\sum(\mathrm{Yi}(\mathrm{Yi}-1))\right.\right.\right.}{\mathrm{NB}(\mathrm{NB}-1)}$
Untuk mengetahui hubungan faktor lingkungan dengan kelimpahan dianalisis menggunakan anava. Pola kunjungan harian serangga polinator bunga apel dianalisis dengan membandingkan rata-rata kunjungan pada periode I, II, III dan IV.

\section{HASIL}

\section{Struktur Komunitas Serangga pada Tumbuhan Penutup Tanah}

Berdasarkan hasil pengamatan terhadap serangga yang terdapat pada beberapa tumbuhan penutup tanah Cyperus rotundus, Bidens pilosa, Commelina difussa, Capsicum frutescens, dan Ageratum conyzoides yang terdapat di area kebun apel varietas Manalagi sepanjang musim bunga diperoleh terdiri dari 542 individu yang terdiri dari 8 famili yaitu: Hymenoptera, Diptera, Lepidoptera, Homoptera, Araneida, Dermaptera, Coleoptera dan Hemiptera, sedangkan pada musim berbuah terdiri dari 215 individu yang terdiri dari 6 ordo yaitu: Hymenoptera, Diptera, Lepidoptera, Homoptera, Coleoptera, dan Hemiptera (Tabel 1).

Famili Arthropoda yang mendominasi pada tumbuhan penutup tanah baik pada musim bunga dan musim buah dapat menggunakan indeks nilai penting (INP) (Gambar 1).

Tabel 1. Kelimpahan Serangga pada Tumbuhan Penutup Tanah

\begin{tabular}{llrrrr}
\hline \multirow{2}{*}{ Ordo } & \multirow{2}{*}{ Famili } & \multicolumn{2}{c}{ Musim } & \multirow{2}{*}{ Tot } & \multirow{2}{*}{ (\%) } \\
\cline { 3 - 4 } & & Bunga & Buah & & \\
\hline Diptera & Anthomyzidae & 203 & 63 & 266 & 35,1 \\
Diptera & Chloropidae & 61 & 19 & 80 & 10,6 \\
Diptera & Tabanidae* & 40 & 20 & 60 & 7,9 \\
Hymenoptera & Ichneumonidae & 36 & 23 & 59 & 7,8 \\
Hymenoptera & Vespidae* $^{*}$ & 47 & 10 & 57 & 7,5 \\
Lepidoptera & Pieridae* $^{*}$ & 19 & 12 & 31 & 4,1 \\
Hymenoptera & Apidae* & 26 & 8 & 34 & 4,5 \\
Diptera & Syrphidae* & 12 & 18 & 30 & 4,0 \\
Diptera & Drosophilidae* & 16 & 4 & 20 & 2,6 \\
Diptera & Cullicidae & 15 & 2 & 17 & 2,2 \\
Diptera & Sarcophagidae & 14 & 0 & 14 & 1,8 \\
Diptera & Muscidae & 12 & 0 & 12 & 1,6 \\
Diptera & Tephritidae & 5 & 5 & 10 & 1,3 \\
Coeloptera & Coccinelidae & 1 & 9 & 10 & 1,3 \\
Hymenoptera & Pompilidae & 3 & 0 & 3 & 0,4 \\
Lain-lain & & 32 & 22 & 54 & 7,1 \\
\hline Jumlah & & $\mathbf{5 4 2}$ & $\mathbf{2 1 5}$ & $\mathbf{7 5 7}$ & $\mathbf{1 0 0}$ \\
\hline Ket: (*) Serangga polinator & & & &
\end{tabular}

Ket: $\left(^{*}\right)$ Serangga polinator 


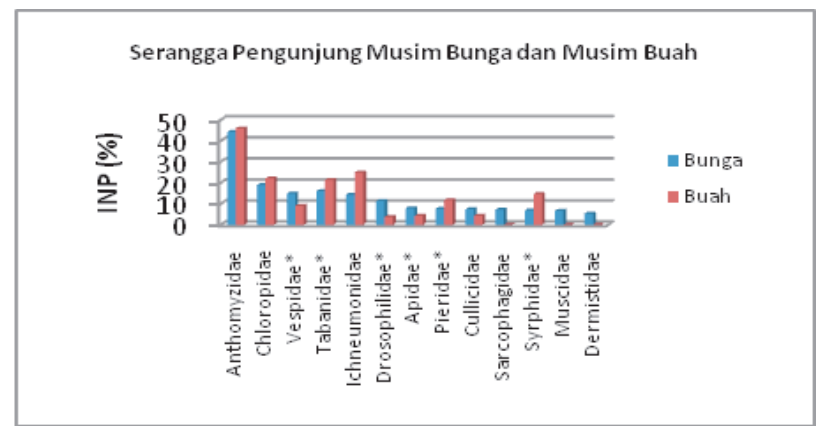

Ket: * = Serangga polinator

Gambar 1. Nilai INP serangga pada tumbuhan penutup tanah

Berdasarkan hasil uji statistik kelimpahan serangga pengunjung pada musim bunga dengan musim buah menggunakan anava juga menunjukkan signifikan dengan $\mathrm{P}<0,05$.

\section{Komposisi Serangga Polinator yang berkunjung pada Tumbuhan Penutup Tanah di Sekitar Kebun Apel}

Total kelimpahan serangga polinator yang dikoleksi saat musim bunga (167 individu) atau 31\% lebih besar musim buah (53 individu) atau 25\% (Gambar 2) yaitu Famili Vespidae, Syrpidae, Tabanidae, Pieridae, Drosophilidae, Apidae dan Danaidae. Sedangkan famili yang tidak ditemui pada musim buah adalah famili Danaidae.

Analisis statistik kelimpahan atau jumlah individu serangga polinator pada tumbuhan penutup tanah pada musim bunga dan buah berbeda nyata dengan nilai $\mathrm{P}<0.020$ sehingga terdapat perbedaan kelimpahan serangga polinator antara musim bunga dengan musim buah.

Kelimpahan relatif serangga polinator pada musim bunga dan buah disajikan pada Gambar 3 .

Berdasarkan hasil penelitian dapat diketahui bahwa masing-masing plot pada musim bunga dan musim buah ditemukan perbedaan jenis dan jumlah serangga polinator (Gambar 4 dan 5).
Kelimpahan serangga musim bunga

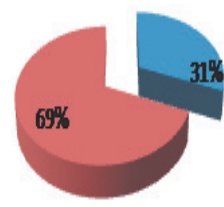

(A)

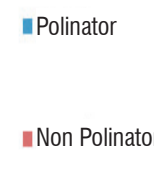

Kelimpahan serangga musim buah

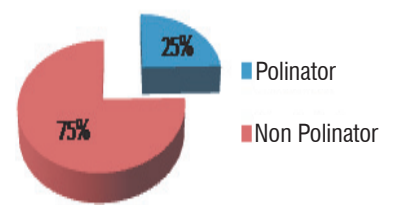

(B)
Gambar 2. Kelimpahan serangga polinator dan non polinator Musim Bunga (A) dan Buah (B)

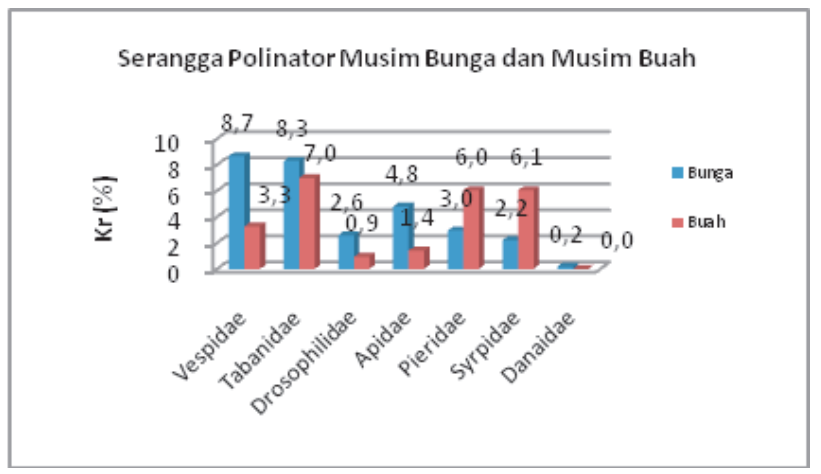

Gambar 3. Kelimpahan relatif serangga polinator

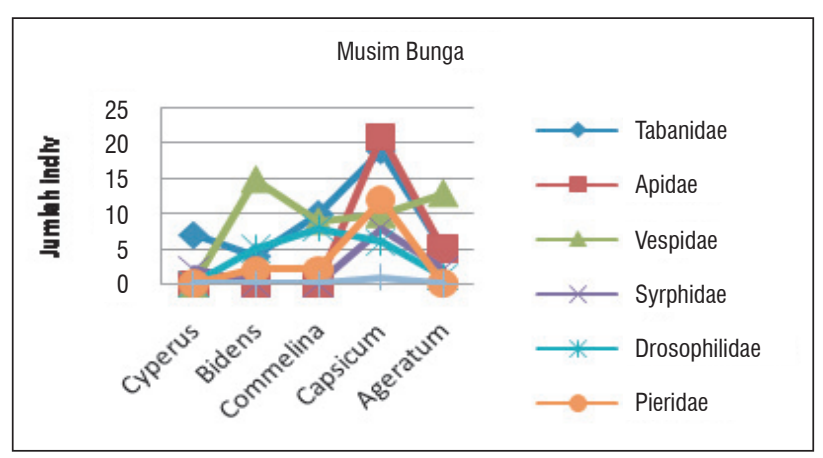

Gambar 4. Grafik kelimpahan serangga polinator pada musim bunga.

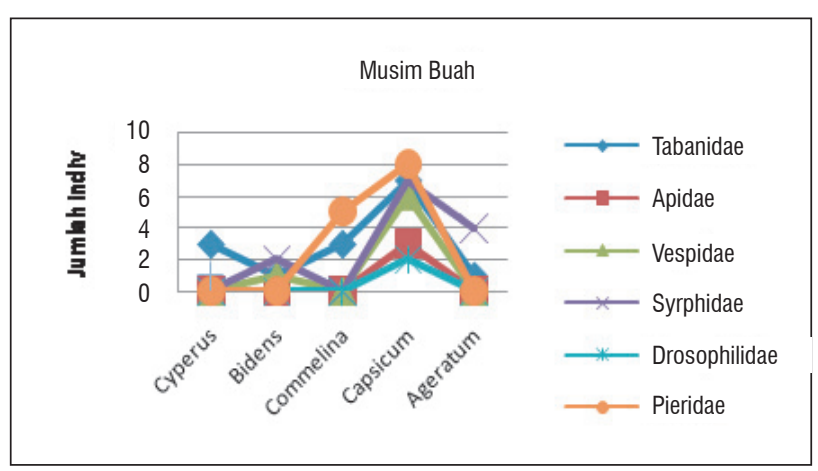

Gambar 5. Grafik kelimpahan serangga polinator pada musim buah

Berdasarkan perhitungan indeks Kesamaan Morisita untuk dilihat kesamaan antara dua komposisi penyusun komunitas tumbuhan penutup tanah musim bunga dan musim buah adalah sebesar $82,4 \%$. Kompoisi serangga polinator pada masing-masing tumbuhan dapat dilihat dari yang terkecil sampai terndah (Tabel 2). 
Tabel 2. Kesamaan Komposisi Serangga Polinator Pada Tumbuhan Penutup Tanah Menggunakan Indeks Morisita

\begin{tabular}{lc}
\hline \multicolumn{1}{c}{ Family } & Kesamaan Morisita \\
\hline Cyperus rotundus & 0,549 \\
Bidens Pilosa & 0,674 \\
Commelina difussa & 0,877 \\
Capsicum frutescens & 0,941 \\
Ageratum conyzoides & 0,823 \\
\hline
\end{tabular}

\section{Hubungan Kelimpahan dan Diversitas Serangga dengan Faktor Lingkungan}

Faktor lingkungan yang diamati pada penelitian ini adalah suhu udara $\left({ }^{\circ} \mathrm{C}\right)$, kelembapan udara dan intensitas cahaya (Lux). Berikut adalah hasil pengamatan suhu, kelembapan dan intensitas cahaya pada lokasi penelitian (Gambar 6, 7, dan 8).

Hasil pengukuran faktor lingkungan dilakukan kompilasi untuk mendapatkan hubungan korelasi antara faktor lingkungan dengan kelimpahan serangga. Analisis dilakukan dengan Regresi, hasil pengujiannya disajikan pada. Nilai Adjusted R-Square sebesar 0,875 atau 87,5\% kelimpahan dari serangga polinator dipengaruhi oleh

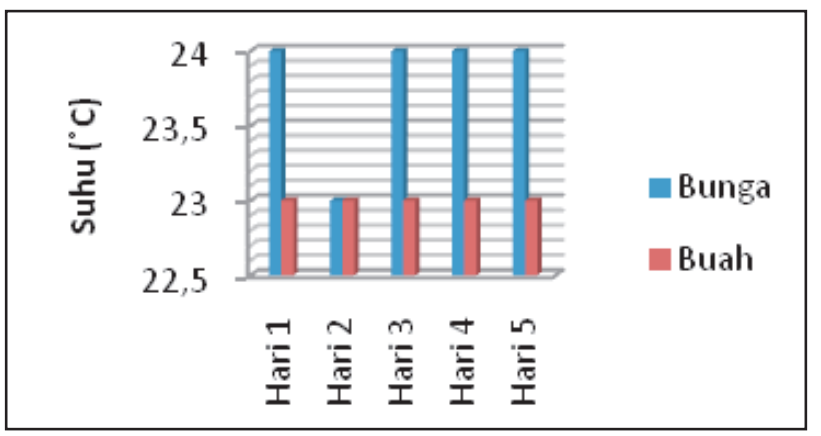

Gambar 6. Perbandingan Rata-rata Suhu Udara $\left({ }^{\circ} \mathrm{C}\right)$ Saat Musim Berbunga dan Berbuah.

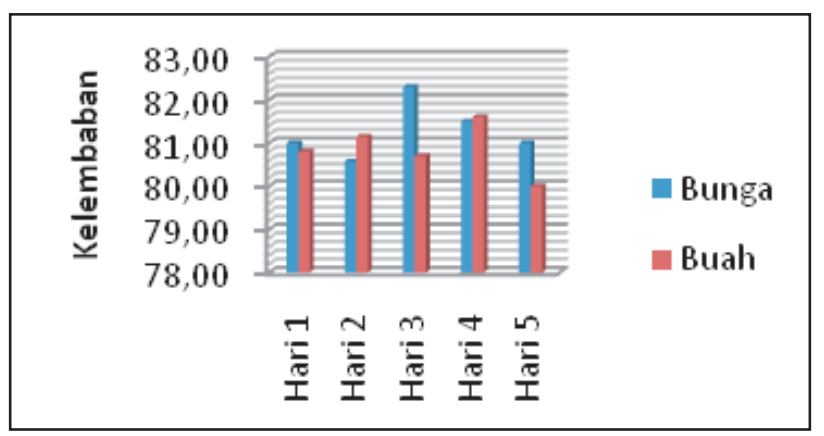

Gambar 7. Perbandingan Rata-rata Kelembapan Udara Saat Musim Berbuah dan Berbunga.

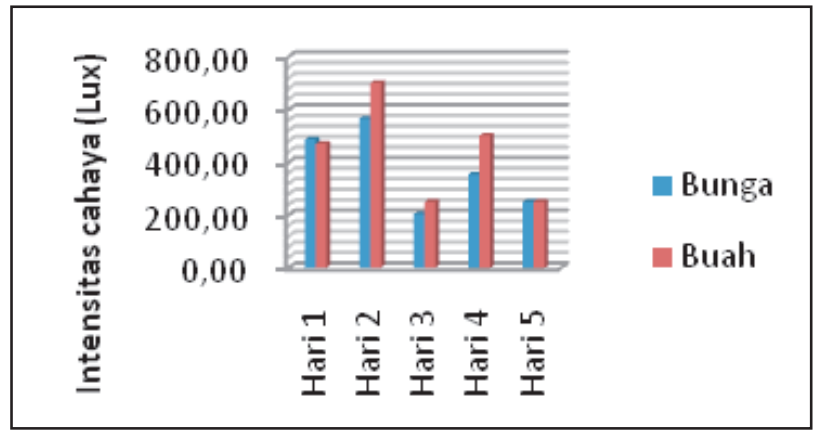

Gambar 8. Perbandingan Rata-Rata Intensitas Cahaya (Lux) Saat Musim Berbunga dan Berbuah.

suhu, kelembapan dan cahaya, sedangkan sisanya $12,5 \%$ dipengaruhi oleh faktor lain. Sehingga didapatkan korelasi antara kelimpahan serangga dengan faktor lingkungan, di mana korelasi antara faktor lingkungan dengan kelimpahan serangga rendah.

\section{PEMBAHASAN}

\section{Struktur Komunitas Serangga pada Tumbuhan Penutup Tanah}

Perbedaan jumlah famili pada musim bunga dan buah di sekitar kebun apel dipengaruhi oleh beberapa faktor, termasuk ketersediaan makanan dan tempat tinggal (Jumar, 2000). Hal ini selaras dengan hasil penelitian yang menunjukkan bahwa jenis serangga yang ditemukan pada saat pengamatan cukup beragam. Keberadaan Arthropoda baik musuh alami, hama dan penyerbuk ini diduga dipengaruhi oleh ketersediaan makanan dan tempat tinggal alternatif berupa tumbuhan penutup tanah yang berada di sekitar perkebunan apel. Wratten dan Van Emden, 1994 menyebutkan bahwa diversifikasi habitat dapat menyediakan nektar dan polen bagi parasitoid dan predator serta dapat berfungsi sebagai tempat berlindung sementara.

Keanekaragaman serangga pada musim bunga $\left(\mathrm{H}^{\prime}\right.$ $=2,308)$, sedangkan keanekaragaman serangga pada musim berbuah $\left(\mathrm{H}^{\prime}=2,237\right)$. Sehingga dapat diartikan keanekaragaman pada musim bunga dan musim buah hampir sama yaitu sedang atau medium $\left(\mathrm{H}^{\prime}>2-3\right)$ (Barbour et al., 1987). Untuk frekuensi kunjungan serangga pada musim bunga juga lebih tinggi dibandingkan pada musim buah. Hal ini disebabkan karena pada musim berbunga ketersediaan makanan lebih banyak dibandingkan pada musim buah, selain itu tumbuhan penutup tanah yang terdapat di sekitar tanaman apel berupa Cyperus rotundus, 
Bidens pilosa, Commelina difussa, Capsicum frutescens, Ageratum conyzoides dalam penelitian ini terbukti mampu menghadirkan beberapa jenis Arthropoda. Nentwig and Poehling (1994) menjelaskan bahwa peningkatan keanekaragaman spesies tanaman berkolerasi positif terhadap peningkatan kekayaan spesies serangga.

Berdasarkan jumlah INP pada gambar 2 menunjukkan bahwa kedua musim tersebut diketahui bahwa serangga dari famili Anthomyzidae menempati dominansi tertinggi yaitu sebesar dari nilai INP Anthomyzidae pada musim bunga dengan nilai 44,22 dan nilai INP sebesar 45,91 pada musim buah. Dari hasil di atas dapat dilihat bahwa secara umum serangga yang mendominasi baik pada musim berbunga maupun berbuah terdapat pada famili Anthomyzidae dari ordo Diptera disebabkan karena serangga ini merupakan serangga kelompok lalat rumput yang mempunyai ukuran tubuh kecil, kadang-kadang memanjang, satu pasang rambut-rambut terakhir di muka mengarah ke depan. Famili Antomyzidae termasuk ordo Diptera ini banyak ditemukan di rumput-rumputan dan pertanaman rendah, khususnya di areal padang rumput atau perkebunan budi daya. Larva hidup di dalam rumput rawa atau paya dan rumput-rumput gulma lainnya (Siwi, 2006).

Berdasarkan perhitungan indeks Morisita dapat diketahui kesamaan komposisi serangga pengunjung tumbuhan penutup tanah musim bunga dengan musim buah tergolong tinggi yaitu $94,1 \%$. Sedangkan tumbuhan yang memiliki kesamaan komposisi terbesar yaitu pada tumbuhan Cyperus rotundus (91,7\%) dan Commelina difussa $(93,4 \%$. Hal ini menunjukkan bahwa tumbuhan-tumbuhan tersebut dapat menarik serangga polinator untuk hadir baik sebagai tempat tinggal sementara, makanan alternatif, tempat pengungsian atau memang tumbuhan-tumbuhan tersebut memang disukai oleh serangga. Di samping itu tumbuhantumbuhan tersebut diduga dapat mendatangkan beragam famili serangga yang berarti dapat menstabilkan rantai makanan dalam suatu perkebunan.

\section{Komposisi Serangga Polinator yang berkunjung pada Tumbuhan Penutup Tanah di Sekitar Kebun Apel}

Kelimpahan serangga polinator pada musim bunga lebih besar daripada musim buah dikarenakan melimpahnya jenis makanan yang tersedia bagi serangga, di samping itu serangga polinator mengunjungi bunga apel karena adanya faktor penarik yaitu bunga, warna bunga, serbuk sari dan nektar (sebagai penarik primer) dan aroma (sebagai penarik sekunder).
Keanekaragaman serangga penyerbuk pada suatu habitat berhubungan erat dengan sumber pakan (polen dan nektar) serta parameter lingkungan (Boulter et al., 2005).

Pada musim bunga kelimpahan relatif ( $\mathrm{Kr}$ ) serangga polinator terbanyak yaitu dari seluruh jumlah serangga pengunjunga adalah famili Vespidae $(8,7 \%)$, hal ini disebabkan karena serangga jenis ini merupakan serangga tabuhan yang dalam siklus hidupnya mampu berperan sebagai polinator dan predator, di samping itu kelimpahan serangga polinator dari Vespidae tidak lepas dari pemangsaan dari predator sehingga polinator dari Vespidae ini tetap tinggi. Kelimpahan serangga Vespidae tetap tinggi diduga karena jenis ini memiliki daya jelajah yang tinggi, di mana sepanjang hari imagonya aktif terbang dan mampu terbang cukup jauh (Ruppert, 1992).

Terbanyak kedua yaitu famili Tabanidae (8,3\%) yang juga merupakan serangga polinator atau serangga penyerbuk, hal ini telah dibuktikan dalam penelitian Chasanah (2010) yang menyatakan bahwa Tabanidae merupakan lalat dengan ukuran tubuh sedang atau besar, panjang 6-20 mm, warna tubuh cokelat, mata besar, membran sayap lebih gelap dari pada warna tubuhnya juga mengunjungi tanaman $H$. Multiflora dan dikategorikan sebagai serangga penyerbuk karena aktif membantu penyerbukan bunganya.

Serangga dari famili Apidae, Drosophilidae, Syrpidae dan Pieridae juga merupakan serangga polinator yang juga membantu penyerbukan hal ini dibuktikan bahwa serangga yang mengunjungi tanaman jarak pagar di Indramayu, Jawa barat adalah Hymenoptera, Lepidoptera, Diptera, Coeloptera, dan Thysanoptera (Atmowidi, 2007) serangga penyerbuk mengunjungi bunga untuk mencari pakan berupa nektar dan serbuk sari (Barth, 1991). Serangga penyerbuk pada tumbuhan famili Asclepiadaceae adalah Hymenoptera, Lepidoptera, Diptera. Ordo-ordo tersebut menjadi penyerbuk utama pada tumbuhan famili Asclepiadaceae berdasarkan frekuensi kunjungan dan kemampuan membawa polinia adalah lebah tabuhan (Vespidae), Ngengat (Lepidoptera) (Ollerton \& Liede, 1997).

Famili Apidae merupakan lebah yang mempunyai ciri-ciri adanya kobikula (pollen basket) pada permukaan luar tibia tungkai belakang. Korbikula yang berfungsi untuk membawa serbuk sari. Apidae memiliki rambut pada tubuhnya dan probosis yang panjang, struktur tubuh inilah yang menjadikan Apidae sebagai penyerbuk utama pada spesies tumbuhan (Michener, 2000).

Famili-famili dari Diptera yang dalam penelitian ini adalah Syrpidae juga termasuk kategori serangga polinator karena Triplehorn \& Jonshon (2005) menyatakan bahwa 
Ordo Diptera dari famili Bombyliidae, Apioceridae, dan Syrpidae berperan sebagai penyerbuk tumbuhan famili Asclepiadaceae. Famili Pieridae dan Danaidae yang masuk dalam ordo Lepidoptera juga termasuk serangga polinator. Hal ini dibuktikan pada penelitian tentang tanaman jarak pagar (J. Curcas) dan Acalypha wilkesiana didominasi oleh tiga ordo, yaitu Hymenoptera, Diptera dan Lepidoptera (Atmowidi, 2007).

Famili Drosophilidae atau lalat buah juga termasuk serangga polinator. Hal ini dibuktikan dengan penelitian tanaman kopi (C. arabica) yang diberi perlakuan kurungan dan non kurungan, ternyata yang berperan aktif dalam meningkatakan pembentukan buah dan biji adalah dari famili Drosophilidae (Atmowidi, 2007).

Pada musim buah kelimpahan terbanyak pada famili Syrpidae $(3,8)$ hal ini dikarenakan Syrpidae selain berperan sebagai serangga polinator dia juga berperan sebagai predator yang mempunyai ketertarikan tinggi terhadap tumbuhan liar, selain itu Syrpidae merupakan serangga diurnal sehingga aktivitasnya dapat dipengaruhi oleh intensitas cahaya. Dan terbanyak kedua adalah serangga dari famili Vespidae.

Dari hasil pengamatan pada saat musim bunga ada satu famili serangga polinator yang tidak ditemui pada musim buah yaitu famili danaidae (ordo Lepidoptera). Tidak hadirnya serangga ini dikarenakan famili jenis kupu ini selain aktif pada siang hari, serangga ini termasuk predator yang memang jarang ditemui pada tanaman semak (Hadi et al., 2009).

Kunjungan serangga polinator pada masing-masing plot pada musim bunga dan musim buah disebabkan oleh beberapa faktor, misalnya aroma yang dikeluarkan bunga yang disukai oleh serangga tertentu, ketersediaan makanan yang tersedia, adanya predator, dan faktor lingkungan misalnya suhu, cahaya dan kelembapan.

Pada musim bunga, famili Vespidae lebih mendominasi pada plot 1 dan plot 3 yaitu pada tumbuhan Cyperus rotundus dan tumbuhan Commelina difussa disebabkan karena famili jenis ini selain berperan sebagai serangga polinator, famili tabuhan (Vespidae) ini merupakan serangga penyerbuk yang penting dan dapat menghasilkan hasil buah pada tumbuhan Aslepiadaceae, (Ollerton \& Liede, 1997).

Selain itu famili ini juga diduga menyukai semua tanaman penutup tanah karena pada tiap plot famili ini cukup mendominasi walaupun pada plot 4 kelimpahannya lebih sedikit. Maisyaroh (2011) menjelaskan berdasarkan uji preferensi bahwa Vespidae mempunyai ketertarikan yang cukup tinggi terhadap tumbuhan liar yang ada di persawahan atau perkebunan. Hasil penelitian yang menunjukkan bahwa tanaman Cyperus rotundus dan Commelina difussa mendukung kehidupan famili Vespidae tersebut dan mampu menjadi habitat alternatif dan memberikan ketersediaan makanan yang cukup menguntungkan.

Pada plot 2 dan plot 4 yaitu pada tumbuhan Bidens pilosa dan Ageratum conyzoides menunjukkan bahwa kelimpahan serangga dari famili Tabanidae lebih tinggi dibandingkan serangga lain, hal ini diduga faktor makanan dan senyawa volatil yang dikeluarkan oleh kedua tumbuhan ini menarik serangga ini untuk berkunjung. Serangga famili Tabanidae ini berukuran sedang yang biasanya induknya meletakkan telurnya di permukaan daun atau di atas air, tapi dewasa jantan terdapat pada bunga-bunga untuk mengambil polen/nektar sehingga serangga ini juga disebut sebagai serangga polinator, sedangkan betina penghisap darah dan sering sebagai hama (Siwi, 2006).

Pada plot 4 atau pada tumbuhan cabe (C. Frutencens) didominasi oleh famili Apidae yaitu serangga penyerbuk yang diduga menjadikan tumbuhan cabe sebagai alternatif habitat dan menjadikan bunga cabe sebagai makananan alternatif setelah bunga apel, karena letaknya yang lebih dekat dengan tanaman apel karena berperan sebagai tanaman tumpangsari. Kondisi ini sangat menguntungkan dalam perkebunan, karena famili Apidae ini mampu berperan sebagai serangga polinator utama pada tumbuhan apel dan keberadaannya tidak akan mengganggu tanaman budi daya karena adanya habitat yang lain yaitu berupa tanaman cabe dan tumbuhan penutup tanah lainnya.

Sementara itu famili Drosophilidae dan Pieridae terdapat pada beberapa plot walaupun tidak mendominasi tapi kelimpahannya juga tergolong banyak, diduga serangga dari famili Drosophilidae ini merupakan lalat fitofagus, yaitu kelompok serangga yang memakan berbagai macam bagian tumbuhan mulai dari akar, batang, daun, bunga dan buah, serangga ini dapat pula berperan sebagai pengurai dalam rantai makanan (Borror, 1992).

Sedangkan keberadaan famili Pieridae diduga hanya pengunjung yang membantu penyerbukan bunga apel, dan menjadikan tumbuhan penutup tanah sebagai makanan alternatif tapi tidak menjadikan tumbuhan liar sebagai habitatnya.

Berdasarkan hasil perhitungan indeks Kesamaan Morisita (Tabel 2) menunjukkan persamaan komposisi serangga polinator pada masing-masing tumbuhan penutup tanah yang tertinggi terdapat pada tumbuhan Capsicum (0,941), Commelina difussa $(0,877)$ dan Ageratum conyzides $(0,823)$. Hal ini dikarenakan tumbuhan tersebut mampu menghadirkan beraneka jenis serangga yang dapat menstabilkan rantai makanan, dan terdapat beberapa faktor 
yang menyebabkan tingginya tingkat kesamaan ini antara lain aktivitas kunjungan serangga umumnya pada pagi sampai siang hari, tinggi dan aktivitas di sore hari semakin menurun, ketersediaan makanan, mikrohabitat, predator dan variasi jenis serangga polinator yang ada pada dua tumbuhan itu sama. Hal ini dibuktikan juga dengan indeks keragaman kedua tanaman tersebut tidak jauh berbeda.

Dari 5 macam tumbuhan ada 3 macam tumbuhan penutup tanah yang perlu direkomendasikan untuk dijadikan rekayasa habitat area refugia untuk membantu dan menarik serangga polinator tetap lestari serta meningkatkan produktivitas serta keseimbangan ekosistem di sekitar kebun apel baik pada musim bunga maupun musim buah yaitu Commelina difussa, Capsicum frutencens dan Ageratum conyzoides.

Berdasarkan hasil pengamatan pada tiap waktu pada tumbuhan penutup tanah pada musim bunga dan buah dapat diketahui bahwa serangga polinator secara keseluruhan lebih banyak mengunjungi tumbuhan Capsicum frutescens atau tumbuhan cabe yang frekuensi kunjungannya mengalami puncaknya pada pukul 09.00-10.15 dan mulai menurun pada pukul 15.00-16.15. Banyaknya kelimpahan serangga polinator yang mengunjungi tumbuhan Capsicum frutencens dipengaruhi oleh beberapa faktor, pertama karena tumbuhan ini memang sengaja ditanam oleh petani apel sebagai tanaman tumpang sari sehingga jumlahnya lebih banyak dibandingkan tumbuhan penutup tanah lainnya, dan secara otomatis bunga yang terdapat pada tumbuhan ini jumlahnya juga relatiflebih banyak sehingga menarik serangga polinator untuk mengunjunginya. Kedua, Kunjungan serangga polinator terhadap tumbuhan Capsicum frutescens ini diduga kerimbunan tajuknya merupakan tempat persarangan yang ideal bagi berbagai jenis musuh alami, dan menjadi habitat yang mampu menyediakan berbagai sumber daya seperti alternatif, sumber makanan untuk kelangsungan hidup dan diversitas serangga tertentu. Diversifikasi habitat juga dapat menyediakan nektar dan pollen bagi serangga khususnya serangga polinator serta dapat berfungsi sebagai tempat berlindung sementara. Pollen dan madu dari gulma atau tanaman liar yang berbunga tersebut dapat berfungsi sebagai sumber makanan alternatif bagi serangga khususnya seranga polinator (Smith, 1992).

\section{Hubungan Kelimpahan dan Diversitas Serangga dengan Faktor Lingkungan}

Berdasarkan persamaan regresi dengan uji koefisien dapat diketahui bahwa faktor kelembapan pada musim bunga berkorelasi positif terhadap kelimpahan serangga polinator dengan nilai koefisiensinya 12,277. Sedangkan faktor musim, suhu dan cahaya berkorelasi negatif, sehingga dapat berpengaruh menurunkan kelimpahan serangga polinator. Pada musim buah kelimpahan serangga dari setiap temporal mengalami penurunan, karena pada musim buah rata-rata suhu lebih rendah daripada musim bunga, begitu juga dengan faktor intensitas cahaya mempunyai rata-rata lebih tinggi daripada musim bunga, sehingga dapat berpengaruh terhadap kelimpahan serangga. Sedangkan faktor kelembapan tidak terdapat perbedaan yang nyata sehingga tidak begitu berpengaruh terhadap kelimpahan serangga polinator.

Faktor lingkungan antara musim bunga dan musim buah tidak menunjukkan perbedaan yang jauh antara suhu, kelembapan, dan intensitas cahaya namun kelimpahan dan keanekaragaman serangga polinator yang berkunjung pada musim bunga dan musim buah berbeda, hal ini dikarenakan pada musim bunga serangga polinator datang di samping mencari makanan juga membantu penyerbukan, sedangkan pada musim buah kunjungan dan kelimpahan serangga polinator menurun, hal ini disebabkan karena ketersediaan makanan lebih sedikit dibandingkan musim buah, di samping itu terjadinya persaingan dalam mendapatkan makanan pada tumbuhan di sekitarnya juga tinggi, sehingg hanya jenis serangga tertentu yang bisa bertahan. Selain itu intensitas cahaya dan kelembapan lebih tinggi dibandingkan dengan suhu optimum serangga menyebabkan beberapa serangga tidak bisa bertahan. Hal inilah yang menyebabkan berkurangnya kelimpahan serangga.

Suhu udara, intensitas cahaya dan kelembapan udara merupakan faktor penting untuk mempengaruhi aktivitas dan perkembangan serangga, di mana serangga memiliki kisaran suhu udara tertentu untuk hidup. Jumar (2000) menyatakan bahwa kisaran suhu efektif untuk serangga dalam perkembangan hidup adalah antara $15-4^{\circ} \mathrm{C}$. Dengan kisaran suhu optimum untuk berkembangbiak adalah suhu $25^{\circ} \mathrm{C}$. Serangga juga membutuhkan kadar air dalam udara atau kelembapan tertentu untuk beraktivitas. Kelembapan yang tinggi berpengaruh pada distribusi, kegiatan, dan perkembangan serangga. Pada kelembapan yang sesuai serangga lebih toleran terhadap suhu ekstrim (Jumar, 2000). Intensitas cahaya merupakan banyaknya cahaya matahari yang dapat berpengaruh terhadap kehidupan organisme khususnya serangga. Cahaya matahari dibutuhkan secara tidak langsung oleh hewan, akan tetapi sinar matahari dapat dimanfaatkan sebagai suatu penanda akan aktivitas tertentu.

Serangga memanfaatkan sinar matahari untuk proses mencari makan, molting, reproduksi atau peristiwa yang terkait sejarah hidupnya (Leksono, 2007). Cahaya 
mempengaruhi distribusi lokal suatu serangga, sehingga serangga tersebut dapat beraktivitas sesuai dengan respons sinyal yang berasal dari sinar matahari. Beberapa serangga adalah bersifat diurnal, di mana akan beraktivitas pada saat terdapat cahaya matahari dan bersifat nokturnal, di mana akan beraktivitas pada malam hari (Jumar, 2000).

\section{KEPUSTAKAAN}

Atmowidi, T. 2007. Diversity of Pollinator Insect in Relation of seed set of Mustard (Brassica rappa L.; Crusiferae.) Hayati J. Biosci, 14: 155-161.

Bahagiawati, 2001. Manajemen Resistensi Serangga Hama pada Pertanaman Tanaman Transgenik Bt. Buletin AgroBio., 4(1).

Barth, F.G. 1991. Insect and Flowers. The Biology and Partnership. New Jersey: Princeton University Press.

Barbour, M.G., Burk, J.H., dan Pitts, W.D. 1987. Terrestrial Plant Ecology. Chapter 9: Method of Sampling the Plant Community. Menlo Park, Benjamin/Cummings Publishing Co. CA.

Boulter, S.L., Kitching, R.L., Howlett, B.G., dan Goodall, K. 2005. Any Which Way Will do The Pollination Biology of a Northern Australian Rainforest Canopy Tree (Syzygium sayeri: Myrtaceae). Bot. J. Linn. Soc. 149: 69-84.

Borror, D.J., Triplehorn, C.A., dan Johnson, N.F. 1992. Pengenalan Pelajaran Serangga. Edisi Keenam. Penerjemah Soetiyono Partosoejono. Yogyakarta: Gadjah Mada University Press

Chasanah, L.R. 2010. Keanekaragaman dan Frekuensi Kunjungan Serangga Penyerbuk Serta Efektifitasnya Dalam Pembentukan Buah Hoya Multiflora Blume (Asclepiadaceae). Sekolah Pascasarjana Institut Pertanian Bogor.

Frei, G., dan Manhart, C. 1992. Nützlinge und Schadlinge an Kunstlich Angelegten Ackerkraustreifen in Getreidefeldern. Agrarökologie 4.

Hadi, M., Tarwotjo, U., dan Rahadian, R. 2009. Biologi Insekta: Entomologi. Graha Ilmu. Yogyakarta.
Jumar, 2000. Entomologi Pertanian. Jakarta. Rieneka Cipta. Landis, D.A,S.D Wratten, dan Gorr, G.M. 2000. Habitat Manajement To Conserve Natural Enemies of Arthropoda Pest in Agriculture. Annual Riview of Entomology, 45: 175-201.

Leksono, A. 2007. Ekologi: Pendekatan Deskriptif dan Kuantitatif. Bayumedia Publishing. Malang.

Maisyaroh, W. 2011. Pemanfaatan Area Refugia Untuk Menarik Kunjungan Arthropoda di Lahan Pertanian. Tesis. Universitas Brawijaya.

Michener, 2000. The Bees of The World. Baltimore: The John Hopkins Univ Pr.

Nentwig, W., Poehling, H.M. 1994. Insektengesllscften auf Selbstbegrünten und eingesäten Ackerbrachen. Paul Haupt Berne. Switzerland.

Ollerton, J dan Liede, S. 1997. Pollination system in the Asclepiadaceae a survey and preliminary analysis. Bio Linn Soc., 62: 593-610.

Raju, A.J.S., dan Ezradanam, V. 2002. Pollination ecology and Fruiting Behavior in a Monoecious species. Jatropha curcas L. (Euphorbiaceae). Cur. Science, 83: 1395-1398.

Ruppert, V. 1992. Einfluss Blutenreicher Feldranstrukturen of Die Dichte Bluten Beruschender Nutzinsekten Insbesondere der Syrpinae (Diptera: Syrpidae Agrarokologie). Bert. Stuttgart.

Smith, R.L. 1992, Elements of Ecology, Third Edition, Chapman and Hall., New York

Siwi, S.S. 2006. Kunci Determinasi Serangga. Yogyakarta: Kanisius.

Triplehorn, C.A., dan Johnson, N.F. 2005. An Introduction To The Study of Insects. Philadelphia: W.B. Saunders.

Wratten, S.D., and Van Emden, H. 1994. Habitat Manajement for Enchanched Activity of Natural Enemies of Insect Pests. In D.M. Glen, M.P Greaves and H.M Anderson. Ecology and Integreted Farming System. Chilchester. UK. Willey. P. 117-146. 